Article

\title{
Occurrence and Coupling of Heat and Ozone Events and Their Relation to Mortality Rates in Berlin, Germany, between 2000 and 2014
}

\author{
Alexander Krug ${ }^{1,2, * \mathbb{C}}$, Daniel Fenner ${ }^{1} \mathbb{D}$, Achim Holtmann ${ }^{1}$ and Dieter Scherer ${ }^{1}(\mathbb{D}$ \\ 1 Technische Universität Berlin, Institute of Ecology, Chair of Climatology, 12165 Berlin, Germany; \\ daniel.fenner@tu-berlin.de (D.F.); achim.holtmann@tu-berlin.de (A.H.); dieter.scherer@tu-berlin.de (D.S.) \\ 2 German Environment Agency, Section II 1.5 Environmental Medicine and Health Effects Assessment, \\ 14195 Berlin, Germany \\ * Correspondence: a.krug@tu-berlin.de
}

Received: 30 April 2019; Accepted: 21 June 2019; Published: 25 June 2019

\begin{abstract}
Episodes of hot weather and poor air quality pose significant consequences for public health. In this study, these episodes are addressed by applying the observational data of daily air temperature and ozone concentrations in an event-based risk assessment approach in order to detect individual heat and ozone events, as well as events of their co-occurrence in Berlin, Germany, in the years 2000 to 2014. Various threshold values are explored so as to identify these events and to search for the appropriate regressions between the threshold exceedances and mortality rates. The events are further analyzed in terms of their event-specific mortality rates and their temporal occurrences. The results reveal that at least $40 \%$ of all heat events during the study period are accompanied by increased ozone concentrations in Berlin, particularly the most intense and longest heat events. While ozone events alone are only weakly associated with increased mortality rates, elevated ozone concentrations during heat events are found to amplify mortality rates. We conclude that elevated air temperatures during heat events are one major driver for increased mortality rates in Berlin, but simultaneously occurring elevated ozone concentrations act as an additional stressor, leading to an increased risk for the regional population.
\end{abstract}

Keywords: heat wave; air temperature; air quality; ozone; mortality; interaction; Berlin; Germany

\section{Introduction}

Episodes of hot weather and poor air quality have been identified as major concerns for public health. Numerous investigations from different parts of the world consistently show a strong relation between elevated air temperature and increased morbidity and mortality, especially during events lasting for several days [1-10]. Likewise, increased ground-level ozone concentrations are significantly associated with negative health and mortality effects [11,12]. Both stressors are highly temporally correlated, and are thus also discussed as major confounders or effect modifiers to one another when determining their particular health risks, underlining their close relationship [13-15]. Vulnerable groups that are identified to be the most sensitive to both stressors are, among others, the elderly and those who suffer from cardiovascular or respiratory illnesses, as well as people of low socioeconomic status and those living in densely populated areas [16].

So far, few investigations have focused on the combination of these two environmental stressors, although it has been shown that the combined occurrence of both worsens morbidity and mortality effects [17-21]. By stratifying air temperature effects for different levels of ozone concentrations, several studies have found significantly increased heat effects on mortality if accompanied with increased 
ozone concentrations $[17,21,22]$. However, studies focusing on the relation between both stressors themselves, as well as their combined effect on human health, also reveal inconsistent results for different regions or their relative effect-contribution [13,17,23]. A comparison of 25 Italian cities revealed a strong effect modification by ozone concentrations to the air temperature-mortality association only in some cities, whereas other cities showed no effect modification [21]. Similar results were found in a Europe-wide study. However, they found no evidence for an effect modification when heat waves were considered instead of air temperature for any of the cities where the study was carried out [22]. Other investigations could not even find any interaction or confounding between air temperature and ozone to affect all-cause mortality [24,25]. Inconsistencies in the results are mainly attributed to the local-specific characteristics of the city under investigation (e.g., [21-23]). This underlines the need for a better understanding of the mechanisms between these environmental stressors and their resulting health effects.

Physically, both health stressors are closely linked to each other, but the nature of the relationship between air temperature and ozone is highly complex and depends on a number of variables. The formation of ozone as a secondary pollutant is driven by the photochemical oxidation of precursors like volatile organic carbons, methane, and carbon monoxide [26-28]. Strong ozone forming can be observed during days of warm, cloud-free, and calm conditions [29-31]. Persistent atmospheric conditions of low winds speeds accompanied by high air temperature may enhance the accumulation of ozone [32-35]. A study for the United States of America (USA) investigated the co-occurrence of extreme heat events and events of high ozone concentrations as exceedances of the 95th percentile of air temperature and the maximum daily eight-hourly average ozone concentration (MDA8). It was shown that the probability of their co-occurrence is up to $30 \%-50 \%$, especially when lasting for multiple days [36]. But, similar to the regional variabilities of their relations to morbidity and mortality, the correlation between air temperature and ozone concentration itself is also found to be regionally variable $[32,37,38]$.

Climate change projections attest heat waves to become more frequent, more intense, and longer lasting [39,40], and they project an increased probability of air stagnation, which may lead to high ozone concentrations [41]. Exemplarily for the USA, an increased frequency of events of high ozone concentrations by $50 \%$ by the 2050 s is projected [38]. Even under future declining emission scenarios, episodes of high ozone concentrations are expected to become more frequent, mainly because of an increase in weather situations favorable for ozone production like heat waves, air stagnation, or decreased cloudiness and precipitation during summer months [26,35,42].

Few of these investigations specifically focus on urban areas. Although ozone concentrations tend to be lower in cites compared to their rural environments, the opposite is true for air temperature. The term "urban heat island" describes the effect of a higher air temperature within an urban area compared with rural surroundings, which may lead to more frequent and longer lasting heat-waves within cities $[43,44]$. In combination with the high density of citizens living in cities, more people are exposed to potentially hazardous conditions, underlining the importance of understanding the dynamic of weather and air pollution, and its impact on the public.

Therefore, Berlin, Germany, is chosen in this study as an example for a mid-latitude city. Several studies that were already conducted in this city address the impacts of air temperature and ozone concentrations on morbidity and mortality (e.g., [17,45]). However, applying an event-based approach, as only heat events have so far been addressed in relation to mortality $[7,46]$. This approach has the main advantage of exploring not only the relationship between a hazard variable (e.g., air temperature or ozone concentration) to an effect variable (e.g., mortality), but also to deliver a local-specific threshold and information about the timing of these events. Thus, the objectives for this study are (1) to investigate the relationship between air temperature as well as ozone concentrations to crude mortality rates in Berlin, by using an explorative, event-based risk assessment approach; (2) to identify individual events of both stressors, as well as events of their co-occurrence; and finally, (3) to analyze these event types, considering their effect on mortality rates and their temporal occurrence. A quantitative comparison or 
separation of the attributable individual deaths either to air temperature or ozone concentrations is not in the scope of this study.

\section{Data and Methods}

\subsection{Study Area}

This study was carried out for the city of Berlin. The capital of Germany is located in the north-eastern part of the country at $52.5^{\circ} \mathrm{N}$ and $13.4^{\circ} \mathrm{E}$, and spans $37 \mathrm{~km}$ in a north-south and $45 \mathrm{~km}$ in an east-west direction, with an overall area of $892 \mathrm{~km}^{2}$. At the end of the study period in 2014, Berlin had almost 3.4 million inhabitants. The surroundings of the city are predominantly flat land of agriculture and woodlands (Figure 1).

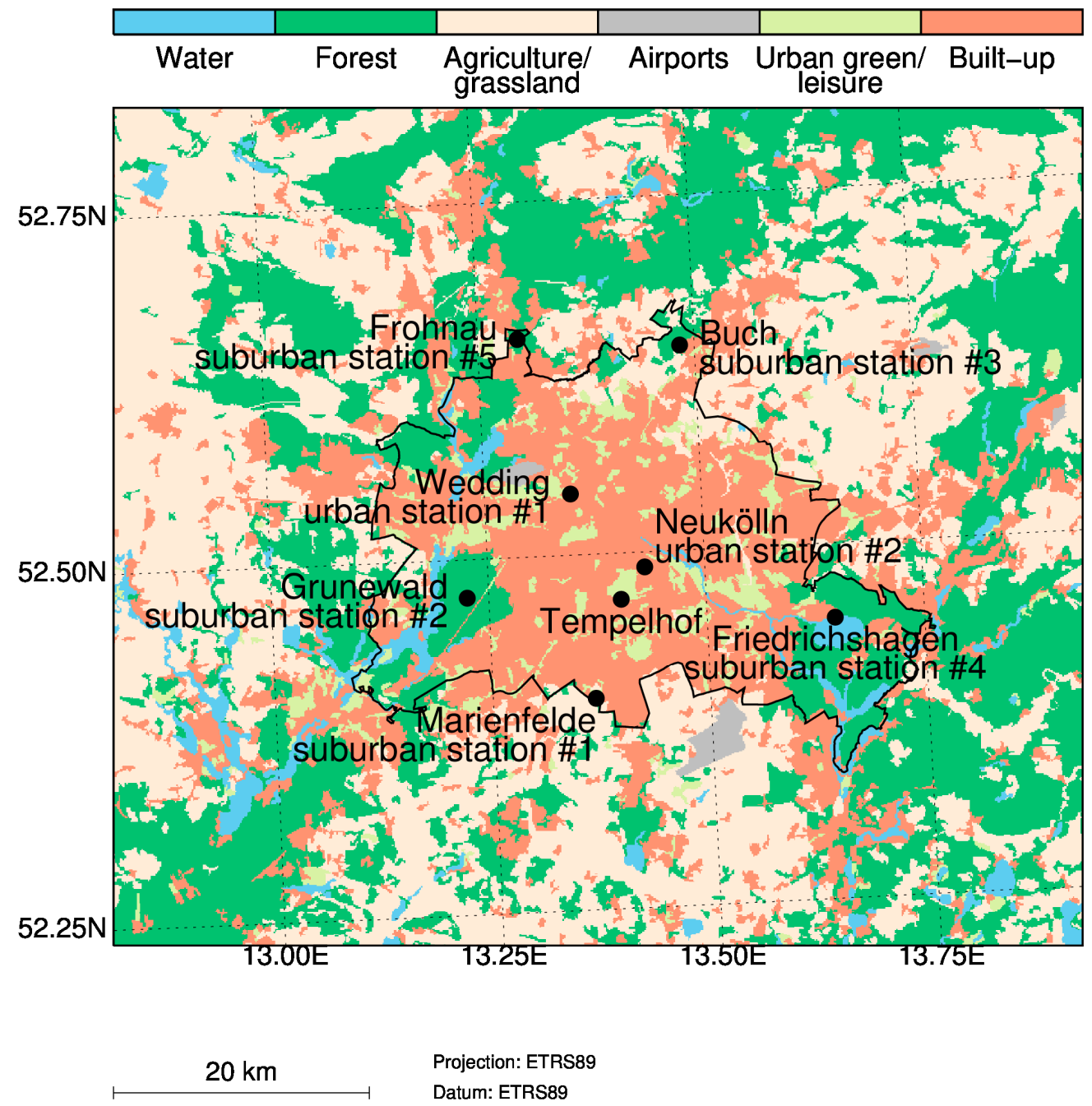

Figure 1. Study area and locations of observation sites of air temperature (Tempelhof) and ozone concentrations (Wedding, urban station \#1; Neukölln, urban station \#2; Marienfelde, suburban station \#1; Grunewald, suburban station \#2; Buch, suburban station \#3; Friedrichshagen, suburban station \#4; and Frohnau, suburban station \#5) in Berlin. Land cover based on CORINE 2012, v18.5. The black line marks the administrative border of the city.

\subsection{Data}

This study uses observational data of air temperature and ozone concentrations from different locations within the urban area of Berlin. The study period is limited to 15 years, from 2000 to 2014 , 
by the common availability of all of the necessary time series of air temperature, ozone concentrations, and daily mortality rates, which are described below in more detail.

The daily average air temperature values $\left(T_{\text {mean }}\right)$ were taken from the site Tempelhof $\left(52.4675^{\circ} \mathrm{N}\right.$, $13.4021^{\circ} \mathrm{E}, 48 \mathrm{~m}$ above mean sea level (amsl)), which is located on a former air field $\left(\sim 3 \mathrm{~km}^{2}\right)$ in the city center (Figure 1). The station is operated by the German Weather Service (DWD) and the data is freely available online [47]. The data from this site has already been used in previous studies, and was shown to be suitable to represent city-wide air temperature conditions $[7,46]$. We used $\mathrm{T}_{\text {mean }}$, as it was shown to be more suitable than, or at least as good as, the daily maximum or minimum air temperature in order to describe heat-related mortality in cities [8,46,48-51]. No significant temporal long-term trend in $\mathrm{T}_{\text {mean }}$ could be observed during the study period.

The ozone concentration data were taken from all seven observation sites of the local air-quality network, located within the urban area of Berlin (Figure 1). The data were provided by the Berlin Senate Department for the Environment, Transport, and Climate Protection [52]. The sites Wedding (urban station \#1) and Neukölln (urban station \#2) are located in a typical urban structure of the inner city, surrounded by buildings of partly commercial and residential use, as well as roads with minor traffic density. These sites are classified as urban background stations so as to represent the exposure of the general urban population, according to the location placement specified by the EU Directive definition [53]. The five observation sites, Marienfelde (suburban station \#1), Grunewald (suburban station \#2), Buch (suburban station \#3), Friedrichshagen (suburban station \#4) and Frohnau (suburban station \#5), are classified as suburban stations, which are located in the outskirts of the city, where highest ozone concentrations occur. These stations are characterized by low density built-up structures, low traffic, and highly vegetated surroundings. Moving eight-hourly averages of ozone concentrations were calculated from hourly values, where the end of the averaging interval indicates to which calendar day it is assigned. We used the daily maximum of these averages (MDA8), as it is the recommended metric by the World Health Organization (WHO) for public health assessment [16]. During the 15-year study period, no significant trend in MDA8 could be observed at any of the sites.

The data of the daily death counts (all ages, all causes of death) were provided by the local statistical office (Statistisches Landesamt Berlin-Brandenburg). The annual population size of Berlin was provided by the federal statistical office [54]. This dataset provides an error-corrected time series of the annual population size for each year's 31 December. These annual data were linearly interpolated to daily values. The daily mortality rate was then calculated as deaths per 1,000,000 inhabitants per day. The mortality data were de-trended for a significant $(p<0.05)$ negative linear trend over the 15 -year study period.

\subsection{Methods}

\subsubsection{Event-Based Regressions}

The event-based risk assessment approach, which is used here, basically follows the concept of risk evaluation for the Intergovernmental Panel on Climate Change (IPCC) [55]. The approach has been adopted and applied by several studies, either to quantify heat-related risks [46,56], or as one option to define heat waves [43]. The approach was developed by and is explained in detail in the literature [46], and is used and configured for this study as described in the following.

In a first step, the approach searches each time series describing the hazard (the one of $\mathrm{T}_{\text {mean }}$ and the seven of MDA8) separately for occurrences of at least three consecutive days exceeding a threshold value. These occurrences are called events hereinafter. For $\mathrm{T}_{\text {mean, }}$ the threshold value is iteratively increased by $1{ }^{\circ} \mathrm{C}$ within the range of $10^{\circ} \mathrm{C}$ to $40{ }^{\circ} \mathrm{C}$, and for MDA8 by $5 \mu \mathrm{g} \mathrm{m}^{-3}$ within the range, from $10 \mu \mathrm{g} \mathrm{m}^{-3}$ to $210 \mu \mathrm{g} \mathrm{m}^{-3}$. The range was set so as to allow for an exploration of the time series without any pre-assumption of the existing thresholds or relations between the hazard and risk variables. At this point, a set of 31 threshold values for $\mathrm{T}_{\text {mean }}$ and 41 threshold values for each MDA8 time series were obtained. For each threshold and each single event, the approach calculates the 
difference between the daily values of the hazard variable and the respective threshold, accumulated over all days of each event. Each value is then logarithmized $(\log 10)$ and is defined as the magnitude. The effect on mortality of each event is represented by the mean daily mortality rate during the event and zero to seven subsequent days (lag days). For each combination of threshold and the number of lag days, a linear regression is then calculated between the event magnitudes and the resulting mortality rates. The base rate is calculated as the mortality rate for zero event magnitude ( $y$-intercept), indicating conditions of no stress. The use of magnitudes as predictor instead of daily values has the advantage of taking not only the intensity of the hazardous process during the event into account, but also their variable length. Each regression delivers a statistical output of the explained variance $\left(r^{2}\right)$, the $p$-value of a two-sided $t$-test, the relative error of the base rate $\left(\mathrm{RE}_{\mathrm{BR}}\right)$, and the relative error of the regression coefficient $\left(\mathrm{RE}_{\mathrm{RC}}\right)$.

The regressions were also calculated for events of minimum duration, different from three days. The chosen minimum duration of three days yielded the best results for both hazard variables in terms of $r^{2}, \mathrm{RE}_{\mathrm{BR}}$, and $\mathrm{RE} \mathrm{RC}_{\mathrm{R}}$.

\subsubsection{Selection of Event-Based Regressions}

The remaining large set of regression models was then filtered for statistical significance $(p<0.05)$, and for each threshold value, the model with the number of lag days yielding the highest $\mathrm{r}^{2}$ was selected. This resulted in a set of statistically significant models for each hazard variable. Each of these models is characterized by a unique combination of a threshold value and the number of lag days. For MDA8, one single time series out of the seven was selected for further analyses, which showed the best statistical results over all of the regression models, and is thus considered to explain the variance of event-specific, city-wide mortality rates the most appropriately (see Section 3.1.2.).

For each of the two remaining sets of regression models ( $T_{\text {mean }}$ and MDA8), three models were selected that revealed high values of $r^{2}$ and low values of $\mathrm{RE}_{\mathrm{BR}}$ and $\mathrm{RE}_{\mathrm{RC}}$. These models were considered as the most appropriate for representing events with low, medium, and high thresholds of both hazard variables. The reason we chose three different models is that it enables to identify potential differences in the regressions to mortality rates for different levels of $T_{\text {mean }}$ or MDA8. Furthermore, we can evaluate the robustness of our results in the comparison of single and coupled events (see Section 2.3.3.).

Our approach allows for an explorative investigation of time series for events and an unprejudiced selection of regression models, so as to assess the local-specific relationship between the risk of either heat or ozone concentrations and event-specific mortality rates. This approach does not allow for any conclusions about individual causes of death, nor do we follow the objective to quantify and distinguish between deaths attributable to heat or ozone. However, the approach enables a risk-based identification and characterization of hazardous heat and ozone events.

\subsubsection{Classification of Single and Coupled Events}

Based on the threshold values of the selected models (see Sections 2.3.1 and 2.3.2), the events of $\mathrm{T}_{\text {mean }}$ (heat events-HE) and MDA8 (ozone events-OE) were then separately classified for further analysis, as follows:

- Single heat events (HEs): Events of $T_{\text {mean }}$ threshold exceedance for at least three consecutive days, and not more than two consecutive days of MDA8 threshold exceedance.

- Coupled heat event (HEc): Events of $\mathrm{T}_{\text {mean }}$ threshold exceedance for at least three consecutive days, and at least three consecutive days of MDA8 threshold exceedance.

- Single ozone events (OEs): Events of MDA8 threshold exceedance for at least three consecutive days, and not more than two consecutive days of $\mathrm{T}_{\text {mean }}$ threshold exceedance.

- Coupled ozone event (OEc): Events of MDA8 threshold exceedance for at least three consecutive days, and at least three consecutive days of $\mathrm{T}_{\text {mean }}$ threshold exceedance. 
This classification is done in order to compare the impact of one stressor on mortality when it is unaccompanied by the second stressor, with its impact when the value of the second stressor exceeds its threshold. This was done by comparing the mean mortality rates during HEs with those during HEc. All HEs and HEc were grouped into classes of similar magnitudes, in range of 0.5 magnitude units. The Mann-Whitney U-test [57] was used to test whether the mean mortality rates during HEs differ significantly from the mean mortality rates during HEc for each class of magnitude, if HEs and HEc showed in at least five events. The procedure was performed analogously for ozone using OEs and OEc. Figure 2 schematically displays different possibilities of the threshold exceedances for $T_{\text {mean }}$ and MDA8, as well as the resulting event types so as to illustrate how the events were classified.

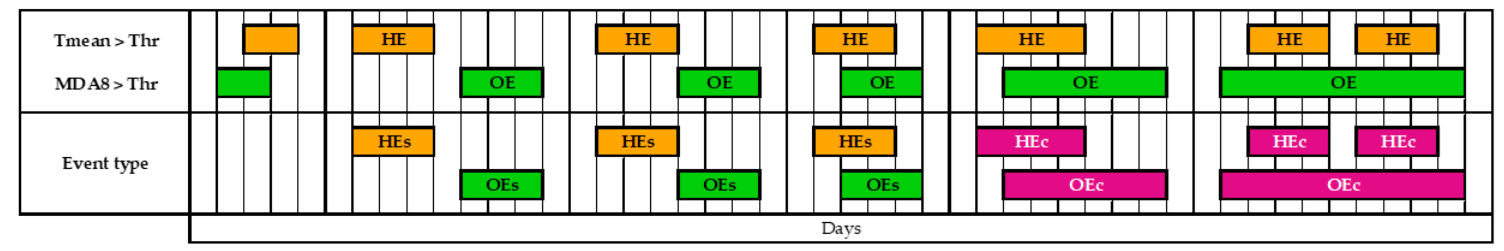

Figure 2. Schematic overview of possible threshold (Thr) exceedances (top row). The resulting heat events (HE) and ozone events (OE) are labeled. The classified event types that were used in the analyses were defined as single heat events (HEs), single ozone events (OEs), coupled heat events (HEc), and coupled ozone events (OEc).

\section{Results}

\subsection{Risk-Based Event Analysis}

\subsubsection{Air Temperature}

Table 1 shows the results of the regression models for $T_{\text {mean }}$. Statistically highly significant $(p<0.01)$ results are found for threshold values from $18{ }^{\circ} \mathrm{C}$ to $24^{\circ} \mathrm{C}$. With an increasing threshold value, $r^{2}$ also increases up to a maximum of $r^{2}=65.8 \%$, which was obtained for the model with the highest threshold value. Three regression models are selected at $\mathrm{T}_{\text {mean }}>20^{\circ} \mathrm{C}$ (five lag days), $\mathrm{T}_{\text {mean }}>22^{\circ} \mathrm{C}$ (four lag days), and $\mathrm{T}_{\text {mean }}>24^{\circ} \mathrm{C}$ (six lag days), representing a low, medium, and high definition for HE. These three options particularly show the high $\mathrm{r}^{2}$ and low relative errors of the regression. Figure 3 displays the regressions of these three selected models.

Table 1. Statistically highly significant $(p<0.01)$ results from the event-based regression analysis for $\mathrm{T}_{\text {mean }}$ measured at site Tempelhof from 2000 to 2014. Thr-threshold value for event detection; percentile-percentile of the threshold value for the whole study period; lag days-lag days included in regression; $\mathrm{N}$ events per year-average number of events per year; $\mathrm{N}$ event days per year-average number of event days per year; $\mathrm{r}^{2}$ - explained variance; $\mathrm{RE}_{\mathrm{BR}}$-relative error of the base mortality rate; $R E_{R C}$-relative error of the regression coefficient (slope). Selected regression models are shaded.

\begin{tabular}{cccccccc}
\hline $\begin{array}{r}\text { Thr } \\
\left({ }^{\circ} \mathbf{C}\right)\end{array}$ & Percentile & Lag Days & $\begin{array}{c}\text { N Events } \\
\text { per Year }\end{array}$ & $\begin{array}{c}\text { N Event Days } \\
\text { per Year }\end{array}$ & $\begin{array}{c}\mathbf{r}^{\mathbf{2}} \\
\mathbf{( \% )}\end{array}$ & $\begin{array}{c}\mathbf{R E}_{\text {BR }} \\
(\mathbf{\%})\end{array}$ & $\begin{array}{c}\mathbf{R E}_{\text {RC }} \\
(\%)\end{array}$ \\
\hline 18 & $\approx 81$. & 5 & 7.5 & 58.2 & 14.2 & 1.5 & 23.5 \\
19 & $\approx 85$. & 4 & 6.5 & 43.3 & 25.0 & 1.8 & 17.8 \\
20 & $\approx 89$. & 5 & 5.3 & 32.1 & 34.5 & 2.0 & 15.6 \\
21 & $\approx 92$. & 6 & 4.1 & 22.2 & 35.0 & 2.8 & 17.8 \\
22 & $\approx 94$. & 4 & 3.3 & 16.0 & 41.9 & 2.6 & 17.0 \\
23 & $\approx 96$. & 6 & 1.8 & 8.3 & 40.3 & 3.1 & 24.3 \\
24 & $\approx 98$. & 6 & 1.1 & 4.9 & 65.8 & 3.2 & 18.6 \\
\hline
\end{tabular}




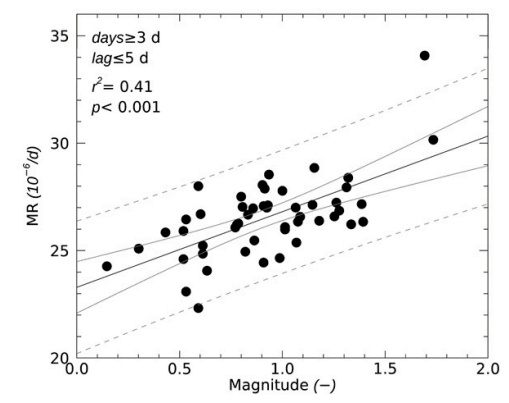

(a)

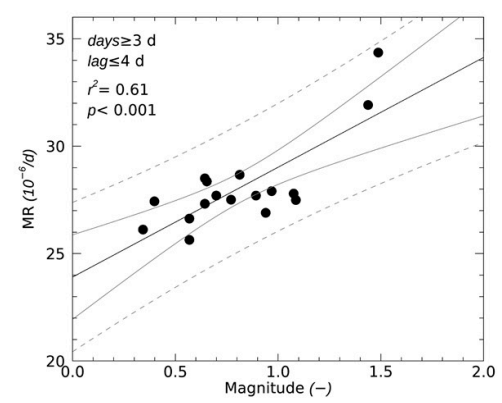

(b)

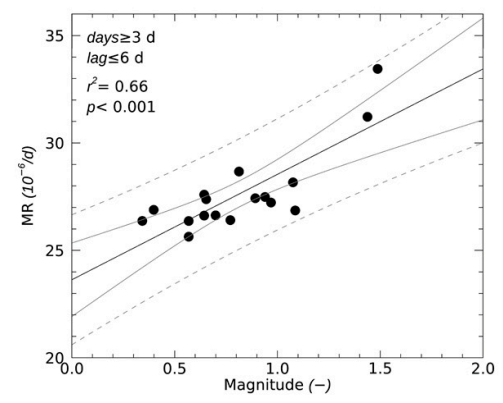

(c)

Figure 3. Regressions between the mean mortality rates (MR; $y$-axis) during HE from 2000 to 2014 in Berlin, and event magnitudes ( $x$-axis) for selected thresholds values. (a) $\mathrm{T}_{\text {mean }}>20^{\circ} \mathrm{C}$ (five lag days);

(b) $\mathrm{T}_{\text {mean }}>22{ }^{\circ} \mathrm{C}$ (four lag days); (c) $\mathrm{T}_{\text {mean }}>24{ }^{\circ} \mathrm{C}$ (six lag days).

\subsubsection{Ozone}

For the seven observation sites, statistically highly significant regressions $(p<0.01)$ were obtained for various MDA8 threshold values between $75 \mu \mathrm{g} \mathrm{m}{ }^{-3}$ and $135 \mu \mathrm{g} \mathrm{m}^{-3}$ (Figure 4). For suburban sites, we found higher $r^{2}$ at higher thresholds compared with the urban background sites. Based on this comparison, we considered site Wedding (urban station \#1) as a good MDA8 predictor for all-cause, city-wide mortality in Berlin. Regressions based on this observation site reveal, in general, good results in view of a combination of high $r^{2}$ and low relative errors (not shown). A low, medium, and high threshold value for event detection was selected at MDA8 $>90 \mu \mathrm{g} \mathrm{m}^{-3}$ (zero lag days), MDA8 $>100 \mu \mathrm{g} \mathrm{m}^{-3}$ (zero lag days), and MDA8 > $105 \mu \mathrm{g} \mathrm{m} \mathrm{m}^{-3}$ (one lag day), respectively. The regression results based on the measurements at site Wedding (urban station \#1) are shown in Table 2 and Figure 5. The results based on the other sites are available in Tables S1-S6 in the supplement.

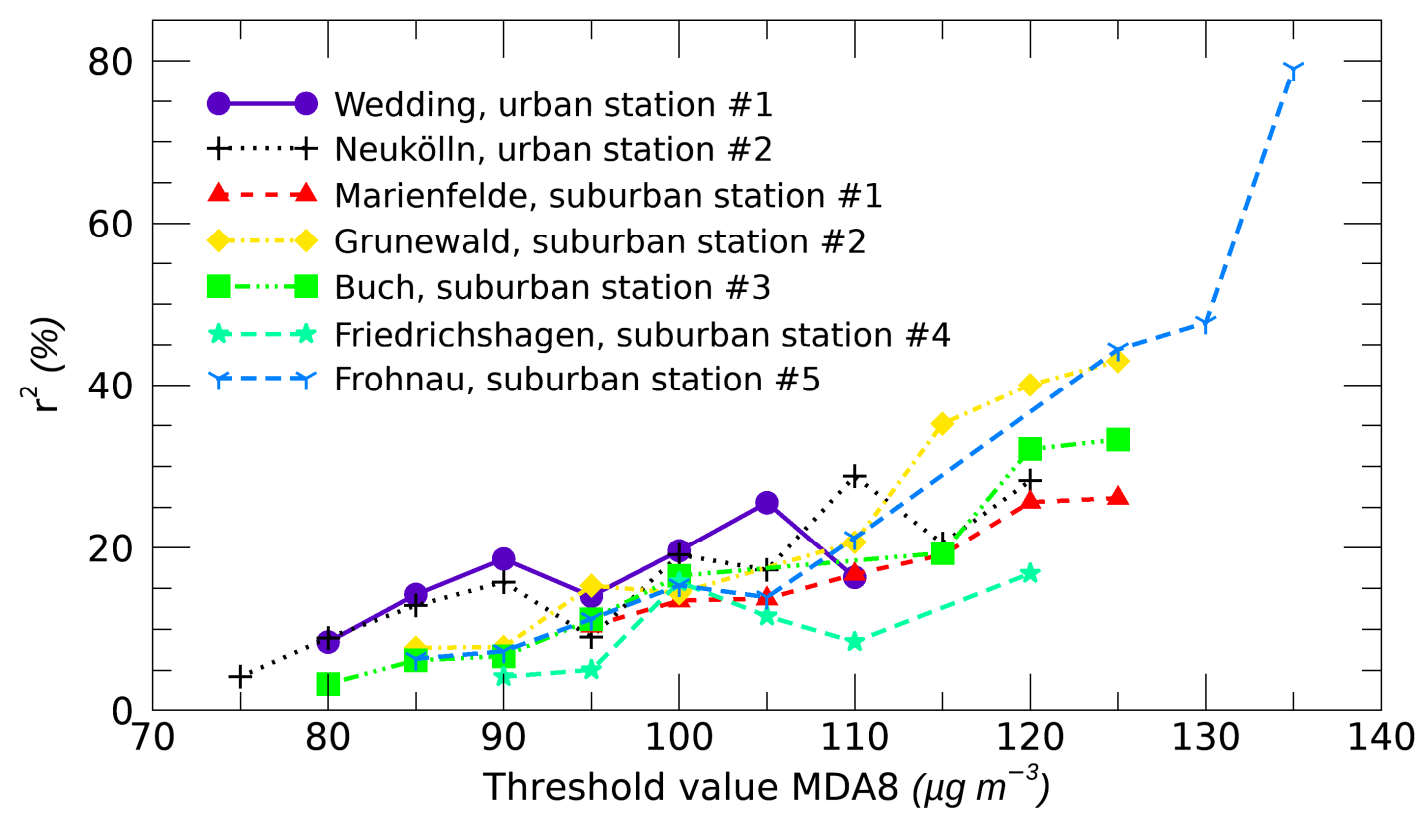

Figure 4. Comparison of the explained variance $\left(r^{2}\right)$ for all of the statistically highly significant $(p<0.01)$ regression models and for different ozone observation sites. The $x$-axis displays the model-specific threshold values. 
Table 2. Same as Table 1, but for the maximum daily eight-hourly average ozone concentration (MDA8) at site Wedding, urban station \#1.

\begin{tabular}{cccccccc}
\hline $\begin{array}{c}\text { Thr } \\
\left(\mu \mathbf{~ m}^{-3}\right)\end{array}$ & Percentile & Lag Days & $\begin{array}{c}\text { N Events } \\
\text { per Year }\end{array}$ & $\begin{array}{c}\text { N Event Days } \\
\text { per Year }\end{array}$ & $\begin{array}{c}r^{2} \\
(\%)\end{array}$ & $\begin{array}{c}\text { RE }_{\text {BR }} \\
(\mathbf{\%})\end{array}$ & $\begin{array}{c}\text { RE }_{\text {RC }} \\
(\mathbf{\%})\end{array}$ \\
\hline 80 & $\approx 75$. & 1 & 10.3 & 73.0 & 8.4 & 2.7 & 26.6 \\
\hline 85 & $\approx 79$. & 0 & 9.1 & 56.9 & 14.2 & 2.9 & 21.2 \\
\hline 90 & $\approx 83$. & 0 & 7.8 & 44.5 & 18.6 & 3.6 & 19.5 \\
\hline 95 & $\approx 86$. & 0 & 6.8 & 35.7 & 14.1 & 3.8 & 24.7 \\
\hline 100 & $\approx 89$. & 0 & 5.3 & 25.9 & 18.5 & 4.4 & 23.9 \\
\hline 105 & $\approx 91$. & 1 & 3.6 & 18.3 & 25.6 & 5.5 & 23.7 \\
\hline 110 & $\approx 93$. & 3 & 2.8 & 13.1 & 16.4 & 6.7 & 35.8 \\
\hline
\end{tabular}

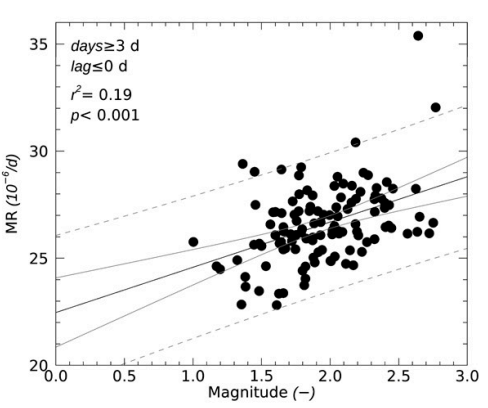

(a)

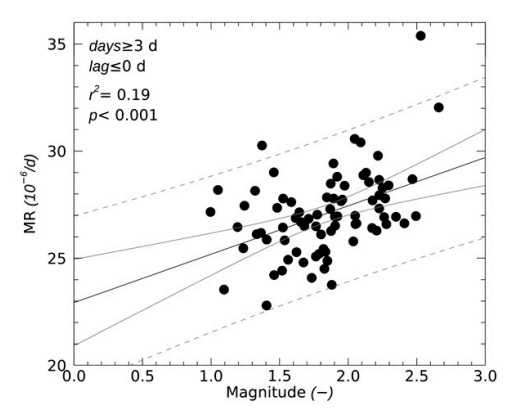

(b)

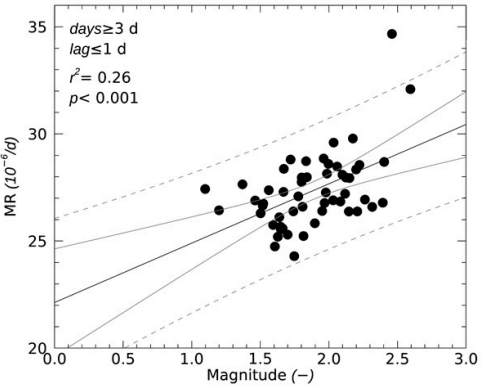

(c)

Figure 5. Regressions between mean mortality rates (MRs; $y$-axis) during OE from 2000 to 2014 in Berlin, and event magnitudes ( $x$-axis) for selected thresholds, based on observations at site Wedding (urban station \#1). (a) Maximum daily eight-hourly average ozone concentration (MDA8) $>90 \mu \mathrm{g} \mathrm{m}^{-3}$ (zero lag days); (b) MDA8 > $100 \mu \mathrm{g} \mathrm{m}^{-3}$ (zero lag days); (c) MDA8 > $105 \mu \mathrm{g} \mathrm{m}^{-3}$ (one lag day).

\subsection{Event Type-Specific Mortality Rates}

Figure 6 compares the classified HEs and HEc on the basis of their relation between event magnitudes $\left(\mathrm{T}_{\text {mean }}\right)$ and mean mortality rates during these events. This is shown for all combinations of the selected $\mathrm{T}_{\text {mean }}$ and MDA8 threshold values. With the exception of high $\mathrm{T}_{\text {mean }}$ threshold values, the majority of events with low to medium magnitudes are HEs. With an increasing event magnitude, the number of HEc increases in relation to the number of HEs. This is observable throughout all of the different threshold combinations, and shows that the higher the magnitude of an HE, the higher the probability that these events are accompanied by high MDA8 values. The most intense events (in terms of magnitude) are HEc (Figure 6, with the exception of two events in Figure 6c). Figure 6g-i reveals that for events defined by the highest threshold value $\left(\mathrm{T}_{\text {mean }}>24^{\circ} \mathrm{C}\right)$, all 17 detected events were accompanied by MDA8 concentrations higher than $100 \mu \mathrm{g} \mathrm{m}^{-3}$, and only two events were not accompanied by MDA8 higher than $105 \mathrm{\mu g} \mathrm{m}^{-3}$. Separate correlations of HEs and HEc reveal highly significant linear relationships between the event magnitudes and mean mortality rates for all HEc throughout all different threshold combinations. For HEs, significant correlations were found for the medium threshold values. However, the strength of the relationship between the event magnitude and mortality rates is stronger for HEc than for HEs. By comparing events of similar magnitudes (magnitude class), HEc revealed significantly $(p<0.05)$ higher mean mortality rates than HEs across all threshold combinations and magnitude classes (Figure 6). The difference in mortality rates becomes larger with an increasing event magnitude. 


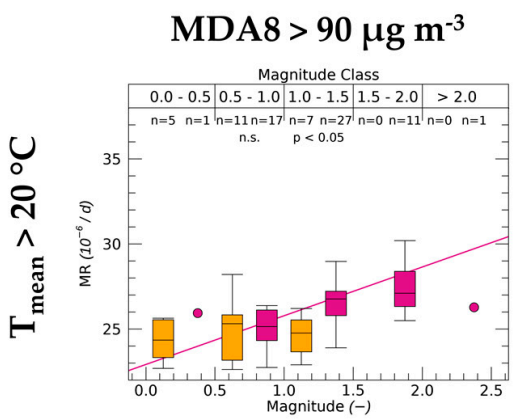

(a)

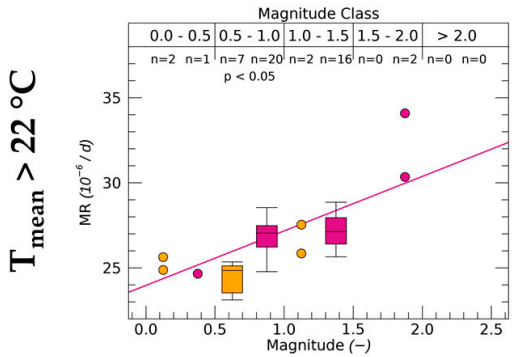

(d)

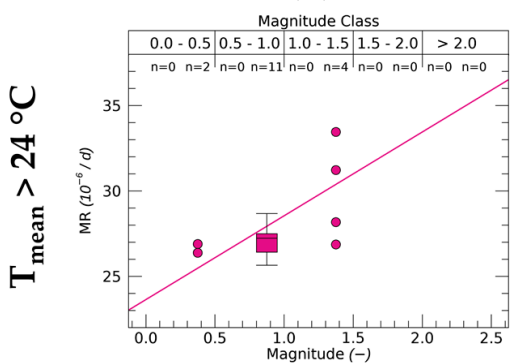

(g)
MDA8 > $100 \mathrm{\mu g} \mathrm{m}^{-3}$

Magnitude Class

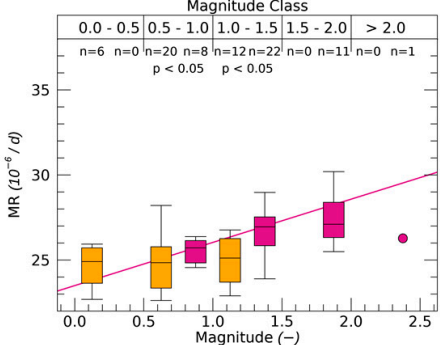

(b)

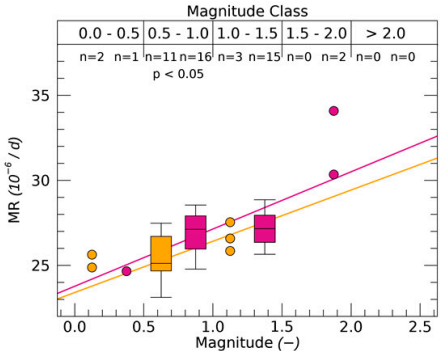

(e)

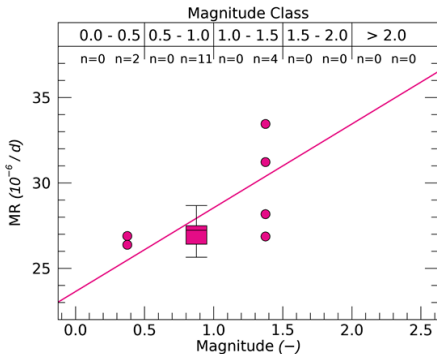

(h)
MDA8 > $105 \mu \mathrm{g} \mathrm{m}^{-3}$

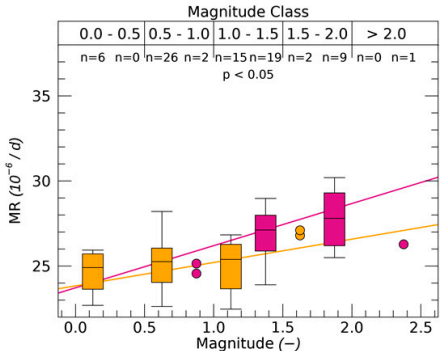

(c)

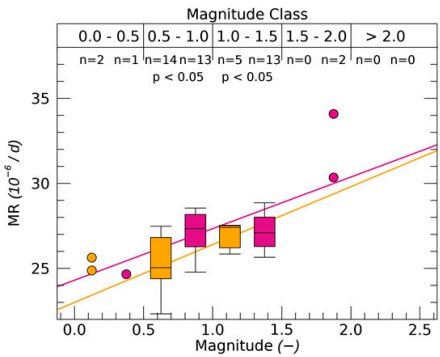

(f)

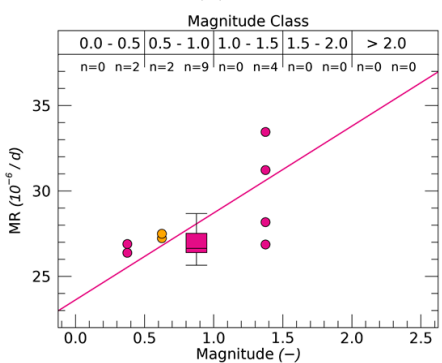

(i)

Figure 6. Comparison of HEs (yellow bars) and HEc (purple bars) with $\mathrm{T}_{\text {mean }}$ as the predictor variable $\left(x\right.$-axis) for daily mortality rates ( $y$-axis) for different threshold combinations $\left((\mathbf{a}) \mathrm{T}_{\text {mean }}>20{ }^{\circ} \mathrm{C}\right.$, MDA8 $>90 \mu \mathrm{g} \mathrm{m}^{-3}$; (b) $\mathrm{T}_{\text {mean }}>20^{\circ} \mathrm{C}$, MDA8 $>100 \mu \mathrm{g} \mathrm{m}^{-3}$; (c) $\mathrm{T}_{\text {mean }}>20{ }^{\circ} \mathrm{C}, \mathrm{MDA} 8>105 \mu \mathrm{g} \mathrm{m}^{-3}$; (d) $\mathrm{T}_{\text {mean }}>22{ }^{\circ} \mathrm{C}$, MDA $8>90 \mu \mathrm{g} \mathrm{m}^{-3}$; (e) $\mathrm{T}_{\text {mean }}>22{ }^{\circ} \mathrm{C}$, MDA $8>100 \mu \mathrm{g} \mathrm{m}^{-3}$; (f) $\mathrm{T}_{\text {mean }}>22{ }^{\circ} \mathrm{C}$, MDA8 > $105 \mu \mathrm{g} \mathrm{m}^{-3}$; (g) $\mathrm{T}_{\text {mean }}>24{ }^{\circ} \mathrm{C}$, MDA8 $>90 \mu \mathrm{g} \mathrm{m}^{-3}$; (h) $\mathrm{T}_{\text {mean }}>24{ }^{\circ} \mathrm{C}$, MDA8 $>100 \mu \mathrm{g} \mathrm{m}^{-3}$; (i) $\mathrm{T}_{\text {mean }}>24^{\circ} \mathrm{C}$, MDA8 $>105 \mu \mathrm{g} \mathrm{m}^{-3}$ ). Separate regression lines (based on individual events) for HEs and HEc are shown if significant $(p<0.05)$. Events are grouped into classes of similar event magnitudes (boxes, top $x$-axis). The edges of each box reflect the 25th and 75th percentile, median values are given as solid lines, and whiskers are the minimum and maximum values, respectively. Less than five events per class are shown as dots. The number of events $(n)$ is displayed above each box. Significant different means (Mann-Whitney U-test) between HEs and HEc are signed at $p<0.05$ per class for $n \geq 5$; $\mathrm{n}$. s. denotes not significant differences.

As for HEs and HEc, Figure 7 compares OEs to OEc. The number of OEc also rises with the increasing event magnitude in relation to the number of OEs. OEc show statistically significant relations between event magnitude and mortality rates in any combination of $\mathrm{T}_{\text {mean }}$ and MDA8 threshold values. For OEs, only in the case of MDA8 $>90 \mu \mathrm{g} \mathrm{m}^{-3}, \mathrm{~T}_{\text {mean }}>22^{\circ} \mathrm{C}$, and MDA8 $>90 \mu \mathrm{g} \mathrm{m}^{-3}, \mathrm{~T}_{\text {mean }}>24^{\circ} \mathrm{C}$ did we find a weak but significant relation between event magnitudes and mortality rates (Figure $7 \mathrm{~d}, \mathrm{~g}$ ). The comparison of events of similar magnitudes showed that at low $\mathrm{T}_{\text {mean }}$ thresholds, mortality rates during OEs were even higher compared to OEc, and significantly higher mean mortality rates for OEc could only be found for medium and high $\mathrm{T}_{\text {mean }}$ thresholds. 


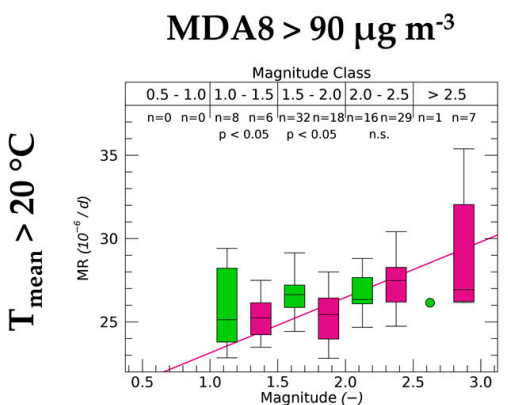

(a)

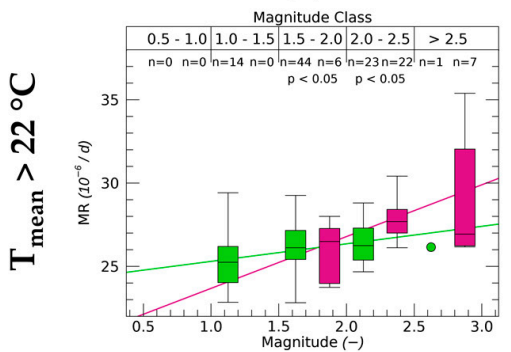

(d)

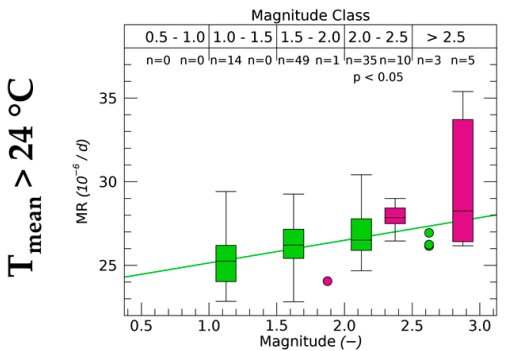

(g)
MDA8 $>100 \mu \mathrm{g} \mathrm{m}^{-3}$

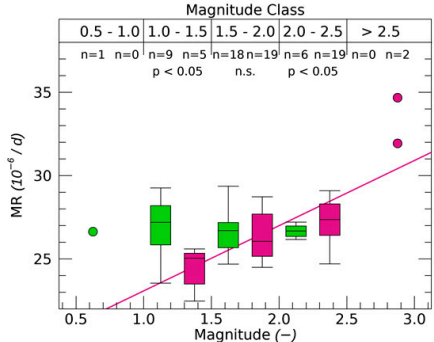

(b)

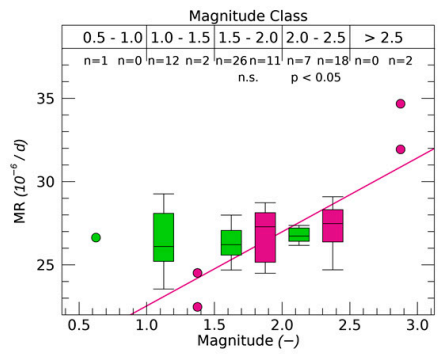

(e)

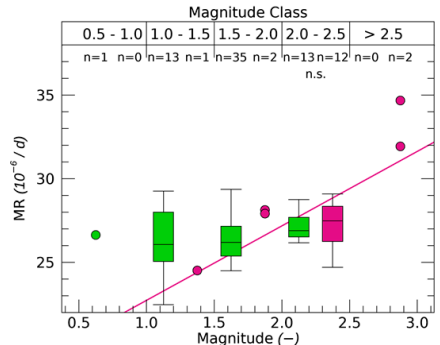

(h)

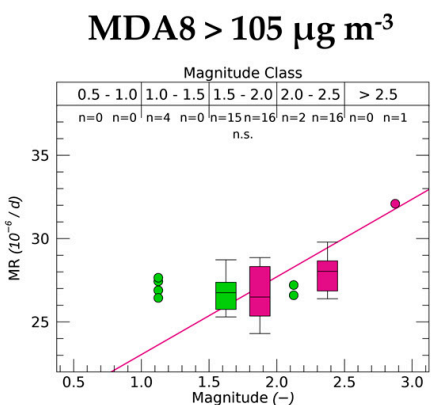

(c)

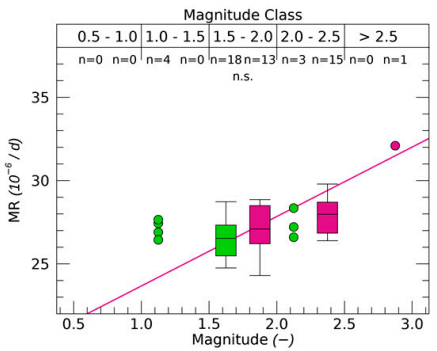

(f)

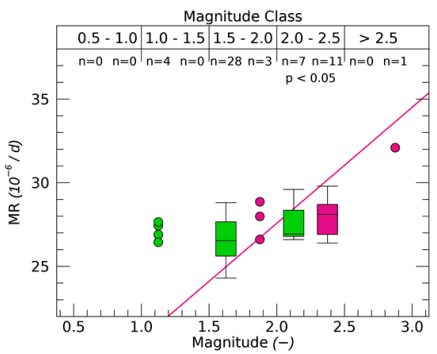

(i)

Figure 7. Comparison of OEs (green bars) and OEc (purple bars) with MDA8 as a predictor variable ( $x$-axis) for the daily mortality rates ( $y$-axis) for different threshold combinations $\left((\mathbf{a}) \mathrm{T}_{\text {mean }}>20^{\circ} \mathrm{C}\right.$, MDA8 > $90 \mu \mathrm{g} \mathrm{m}^{-3}$; (b) $\mathrm{T}_{\text {mean }}>20^{\circ} \mathrm{C}$, MDA8 > $100 \mu \mathrm{g} \mathrm{m}^{-3}$; (c) $\mathrm{T}_{\text {mean }}>20{ }^{\circ} \mathrm{C}$, MDA8 $>105 \mu \mathrm{g} \mathrm{m}^{-3}$; (d) $\mathrm{T}_{\text {mean }}>22{ }^{\circ} \mathrm{C}$, MDA $8>90 \mu \mathrm{g} \mathrm{m}^{-3}$; (e) $\mathrm{T}_{\text {mean }}>22{ }^{\circ} \mathrm{C}$, MDA $8>100 \mu \mathrm{g} \mathrm{m}^{-3}$; (f) $\mathrm{T}_{\text {mean }}>22{ }^{\circ} \mathrm{C}$, MDA8 $>105 \mu \mathrm{g} \mathrm{m}^{-3}$; (g) $\mathrm{T}_{\text {mean }}>24{ }^{\circ} \mathrm{C}$, MDA8 $>90 \mu \mathrm{g} \mathrm{m}^{-3}$; (h) $\mathrm{T}_{\text {mean }}>24{ }^{\circ} \mathrm{C}$, MDA8 $>100 \mu \mathrm{g} \mathrm{m}^{-3}$; (i) $\mathrm{T}_{\text {mean }}>24^{\circ} \mathrm{C}$, MDA8 $>105 \mu \mathrm{g} \mathrm{m}^{-3}$ ). Separate regression lines (based on individual events) for OEs and $\mathrm{OEc}$ are shown if significant $(p<0.05)$. Events are grouped into classes of similar event magnitudes (boxes, top $x$-axis). The edges of each box reflect the 25th and 75th percentile, median values are given as solid lines, and whiskers are the minimum and maximum values, respectively. Less than five events per class are shown as dots. The number of events $(n)$ is displayed above each box. Significant different means (Mann-Whitney U-test) between OEs and OEc are signed as $p<0.05$ per class for $n \geq 5$; n. s. denotes not significant differences.

\subsection{Temporal Pattern of Events}

Across all possible combinations of $\mathrm{T}_{\text {mean }}$ and MDA8 threshold values, we obtained at least $40 \%$ of all HE to be HEc during the study period, and at least $13 \%$ of OE were OEc. Coupled events were mostly frequent during summer months (June, July, and August), and were also the longest events, which was observable for all threshold combinations. During spring months (April and May), OEs were frequent, while during summer months, events of elevated ozone concentrations mostly occurred in combination with a high air temperature. But HEs and OEs were shorter during summer in comparison to coupled events. Figure 8 exemplarily shows the temporal occurrence of all events during the study period for medium threshold values ( $\mathrm{T}_{\text {mean }}>22{ }^{\circ} \mathrm{C}$, MDA $8>100 \mu \mathrm{g} \mathrm{m}^{-3}$ ). Figure 9 shows, that the longer a heat event is, the higher the probability is to be a HEc. As shown in this example, HE that last longer than five days are HEc, while a small number of OEs may last for longer periods. 

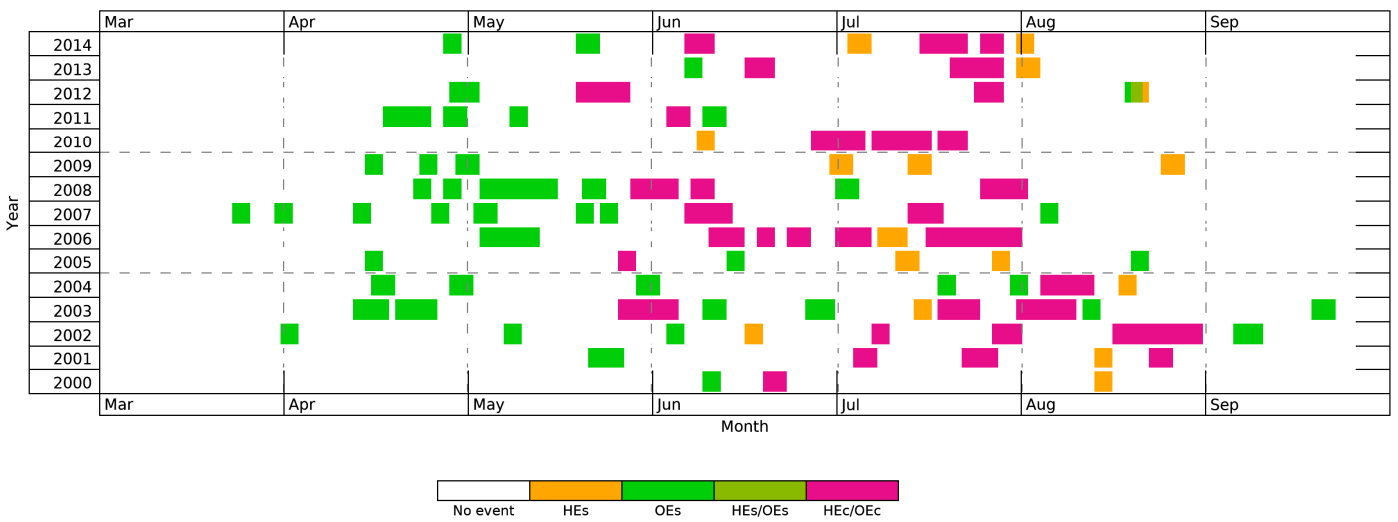

Figure 8. Temporal occurrences of HEs ( $\mathrm{T}_{\text {mean }}>22{ }^{\circ} \mathrm{C}$, orange), OEs (MDA8 $>100 \mu \mathrm{g} \mathrm{m}{ }^{-3}$, green), and corresponding coupled events (HEc/OEc, purple) in Berlin from 2000 to 2014. Overlapping days of HEs and OEs that are not classified as coupled events are marked in olive-green.

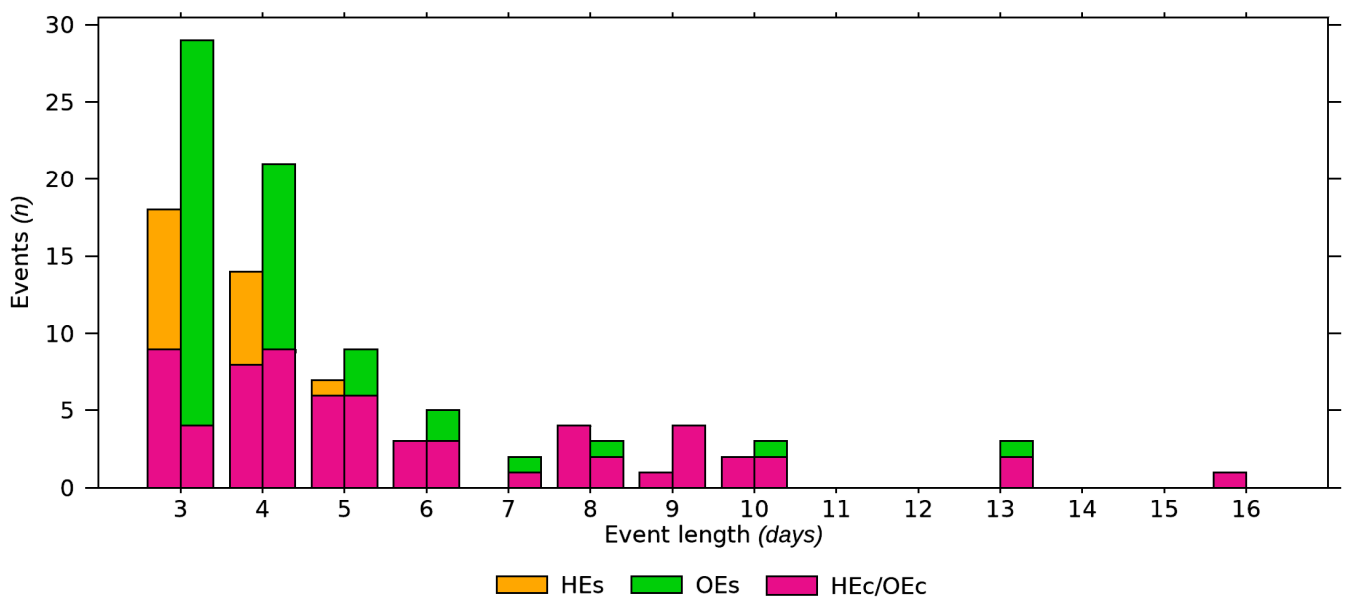

Figure 9. Stacked bars for the number of events per length of HEs ( $\mathrm{T}_{\text {mean }}>22{ }^{\circ} \mathrm{C}$, orange), OEs (MDA8 > $100 \mu \mathrm{g} \mathrm{m}^{-3}$, green), and corresponding coupled events (HEc/OEc, purple) in Berlin from 2000 to 2014.

\section{Discussion}

\subsection{Risk-Based Identification of Heat and Ozone Events}

The results show that by applying an event-based risk assessment approach, heat events and events of increased ozone concentrations can be associated to crude mortality rates in Berlin, Germany. Basically, these results are in consensus with the results shown world-wide for both stressors $[14,16,58,59]$. The majority of studies within this subject use Poisson regressions to investigate the mortality effects of a continuous time series of air temperature and/or ozone concentration. The often reported non-linearity in this relationship (e.g., [20,60,61]) excludes the application of linear regressions. The main difference between these studies and the study at hand is that here, we stratify the time series for events of a variable length that exceed a threshold at the higher end of the range of air temperature and ozone concentrations, and analyze their effect on mortality rates. Thus, the relationship between the event magnitudes and the mean mortality rates has a shape that is not comparable with the shape of the relationship between the whole range of either air temperature or ozone concentrations with mortality.

The use of event magnitudes as a predictor, instead of air temperature or ozone concentrations, takes the intensity of the event and its length into account. We additionally tested for a polynomial regression fit between event magnitudes and mortality rates, but the selection of models and therefore the threshold values used for event detection remained identical. For that reason, linear regressions between magnitudes of these events as predictor and event-specific mortality rates as predictand 
are considered as appropriate in order to explain this relationship (cf. Figures 3 and 5). We found statistically highly significant correlations between event magnitudes and mortality rates for both stressors for events defined by various threshold values. This reveals that no single threshold that reflects one ideal relation to mortality rates being representative for the whole city can be deduced with this method. Significant results for different threshold values may be an effect of inner-city variances. First, people may be exposed to elevated air temperature differently in various districts of one city at the same time, as air temperature varies across different districts [62]. Also, exposure to ozone varies spatially dependent on the availability of precursors $[63,64]$, and tends to be higher in suburban areas compared with inner-city locations. Second, highly vulnerable citizens with multiple pre-existing illnesses may be affected at much lower air temperatures or ozone concentrations than others, whose health conditions are still able to endure the current exposure. This variability is not only causing inner-urban variability, but is also shown in studies that analyze heat or ozone effects on mortality in comparison across different cities (e.g., $[5,8,23,65])$. The inner-urban variability of the exposure to heat and ozone in Berlin is already investigated by the authors of [45], and the inter-urban differences are shown by the authors of [17]. Thus, we argue that the results of this study are city-specific for Berlin, and the exposure of the air temperature and ozone may affect mortality rates differently in other cities. An inter-urban comparison based on this event-based approach could be the objective for further research. Appropriate results for the ozone-mortality relationship are obtained for threshold values between $90 \mu \mathrm{g} \mathrm{m}^{-3}$ and $105 \mu \mathrm{g} \mathrm{m}^{-3}$, which are close to the WHO's guideline of $100 \mu \mathrm{g} \mathrm{m}^{-3}$, which was set so as to reduce the impact of ozone on health [66]. However, this is lower than the current target value for human health protection of $120 \mathrm{\mu g} \mathrm{m}^{-3}$, set by the European Commission, which must not "be exceeded on more than 25 days per calendar year averaged over three years" [53]. This target value was met in Berlin since 2009, but on an annual basis, the threshold of $120 \mu \mathrm{g} \mathrm{m}^{-3}$ was exceeded, between 3 and 45 times during the study period.

\subsection{Influence of Ozone onto Heat Events}

For HE, we could show that the more intense these events are, the higher the probability is to be accompanied with elevated ozone concentrations. This relationship is well investigated, as high air temperatures promote the formation of high ozone concentrations through precursors [35-37,67,68]. This effect may be time-dependent, as we could show for Berlin, that heat events lasting over more multiple days, occurred in combination with elevated ozone concentrations.

Also, weather conditions like air stagnation, high solar irradiance, or elevated air temperature, which are common during heat events, foster ozone forming and accumulation, and thus increase the exposure to ozone $[30,31,41]$. Separate regressions of HEs and HEc strongly depend on the distinct combination of ozone thresholds, whether magnitudes of HEs are significantly related to mortality rates. This underlines that a clear separation of HEs and HEc is not simple. But we consistently show, that with increasing $\mathrm{T}_{\text {mean }}$ magnitude, mortality rates rise with a stronger effect during HEc than HEs. Across all threshold combinations and magnitude classes, HEc show significantly higher mean mortality rates than HEs. We interpret that HEs alone have an impact on mortality, but increased ozone concentrations add an additional health stressor, producing a larger effect on mortality in Berlin. This supports research carried out for other regions, in which ozone was identified to amplify the heat-mortality relationship $[35,58,68,69]$. In particular, highly vulnerable people, who are already physiologically stressed by heat, lose their ability to withstand simultaneously occurring elevated ozone concentrations [70].

\subsection{Influence of Air Temperature onto Ozone Events}

While we found significant correlations between ozone and mortality rates, the separation into OEs and OEc shows that the ozone magnitude of OEs, without coincident high air temperatures, only weakly explains mortality rates during these events. This relationship strongly differs when $\mathrm{OE}$ are temporally accompanied with increased air temperate $(\mathrm{OEc})$. However, we found high mortality rates 
for a number of OEs, especially for events defined by low thresholds (Figure 7). It is possible that these may have been caused by other stressors, like other air pollutants, which were found to affect mortality rates $[18,34,71,72]$, but were not addressed in this study. Another possible explanation could be related to the time of occurrence of these OEs. They frequently occurred during spring months, during which mortality rates are generally higher compared to summer in Germany $[73,74]$. This may explain the high mortality rates during OEs occurring earlier in the year, compared with events occurring during summer months, when almost all OEs are accompanied with HEs. This may possibly also affect the overall relationship between ozone and mortality rates. However, we interpret that the ozone-mortality relationship is mainly driven by co-occurring high air temperatures, either as result of increased formation of ozone during OEc, or through the effect of elevated air temperatures during these events. These results are in consensus with other studies that investigated the modifying impact of air temperature on the ozone-mortality relationship (e.g., [13,58,75]). However, we could not find overall evidence for different thresholds and event magnitudes, that OEc show significantly higher mortality rates compared with OEs.

\section{Conclusions}

This study analyzed heat and ozone events, including their combined occurrence during 15 years from 2000 to 2014 in Berlin, Germany. With an event-based risk assessment approach, the events were deduced based on their overall relationship between daily mean air temperature and maximum daily eight-hourly mean ozone concentration, and crude mortality rates. The events were furtherly stratified into single events of elevated air temperature or ozone concentrations, and events in which both stressors occur. At least $40 \%$ of heat events were shown to be temporally co-occurring with high ozone concentrations, with the highest probability for the most intense and longest heat events. While single ozone events were found to weakly affect mortality rates, heat events produce a stronger effect on mortality rates. In combination with elevated ozone concentrations, this effect was shown to be amplified. We conclude that air temperature is one major driver for mortality rates during summer months. High ozone concentrations add an additional stressor for citizens during heat events, contributing to increased mortality rates during these events. However, further research is needed in order to investigate different cities in various climatic regions so as to identify potential inter-city differences in heat-ozone-mortality interactions.

Supplementary Materials: The following are available online at http://www.mdpi.com/2073-4433/10/6/348/s1, Table S1: Statistically highly significant $(p<0.01)$ results from the event-based regression analysis for MDA8 at site Neukölln (urban station \#2) from 2000 to 2014; Table S2: As Table S1, but for MDA8 at site Marienfelde (suburban station \#1); Table S3: As Table S1, but for MDA8 at site Grunewald (suburban station \#2); Table S4: As Table S1, but for MDA8 at site Buch (suburban station \#3); Table S5: As Table S1, but for MDA8 at site Friedrichshagen (suburban station \#4); Table S6: As Table S1, but for MDA8 at site Frohnau (suburban station \#5).

Author Contributions: Initial conceptualization and methodology, A.K. and D.S.; discussion of results and refinement of methodology, A.K., D.F., A.H., and D.S.; software, A.K., D.F., A.H., and D.S.; formal analysis and writing (original draft preparation), A.K.; writing (review and editing), A.K., D.F., and A.H.; visualization, A.K, A.H., and D.F.; supervision, D.S.

Funding: This research was funded by the Federal Ministry of Education and Research (BMBF), within the framework of Research for Sustainable Development (FONA; www.fona.de), as part of the consortium "Three-dimensional Observation of Atmospheric Processes in Cities" (www.uc2-3do.org), under grant no. 01LP1602. A.K. received funding by the doctoral research program of the German Environment Agency. D.F. received funding from the German Research Foundation, under grant no. SCHE 750/15-1.

Acknowledgments: We give our thanks to the Senate Department for the Environment, Transport, and Climate Protection (SenUVK) for the provision of the air quality data. Special thanks go to Hans-Guido Mücke of the Environment Agency (UBA) for valuable discussions and support.

Conflicts of Interest: The authors declare no conflict of interest. The funders had no role in the design of the study; in the collection, analyses, or interpretation of data; in the writing of the manuscript; or in the decision to publish the results. 


\section{References}

1. Tong, S.; Wang, X.Y.; FitzGerald, G.; McRae, D.; Neville, G.; Tippett, V.; Aitken, P.; Verrall, K. Development of health risk-based metrics for defining a heatwave: A time series study in Brisbane, Australia. BMC Public Health 2014, 14, 435. [CrossRef] [PubMed]

2. Williams, S.; Nitschke, M.; Sullivan, T.; Tucker, G.R.; Weinstein, P.; Pisaniello, D.L.; Parton, K.A.; Bi, P. Heat and health in Adelaide, South Australia: Assessment of heat thresholds and temperature relationships. Sci. Total Environ. 2012, 414, 126-133. [CrossRef] [PubMed]

3. Analitis, A.; Michelozzi, P.; D’Ippoliti, D.; De’Donato, F.; Menne, B.; Matthies, F.; Atkinson, R.W.; Iñiguez, C.; Basagaña, X.; Schneider, A.; et al. Effects of Heat Waves on Mortality. Epidemiology 2014, 25, 15-22. [CrossRef] [PubMed]

4. Gosling, S.N.; Lowe, J.A.; McGregor, G.R.; Pelling, M.; Malamud, B.D. Associations between elevated atmospheric temperature and human mortality: A critical review of the literature. Clim. Change 2008, 92, 299-341. [CrossRef]

5. Gasparrini, A.; Guo, Y.; Hashizume, M.; Lavigne, E.; Zanobetti, A.; Schwartz, J.; Tobias, A.; Tong, S.; Rocklöv, J.; Forsberg, B.; et al. Mortality risk attributable to high and low ambient temperature: A multicountry observational study. Lancet 2015, 386, 369-375. [CrossRef]

6. Hajat, S.; Kosatky, T. Heat-related mortality: A review and exploration of heterogeneity. J. Epidemiol. Community Health 2010, 64, 753-760. [CrossRef] [PubMed]

7. Gabriel, K.M.A.; Endlicher, W.R. Urban and rural mortality rates during heat waves in Berlin and Brandenburg, Germany. Environ. Pollut. 2011, 159, 2044-2050. [CrossRef]

8. Anderson, B.G.; Bell, M.L. Weather-Related Mortality. Epidemiology 2009, 20, 205-213. [CrossRef]

9. De Sario, M.; Katsouyanni, K.; Michelozzi, P. Climate change, extreme weather events, air pollution and respiratory health in Europe. Eur. Respir. J. 2013, 42, 826-843. [CrossRef]

10. Bassil, K.L.; Cole, D.C.; Moineddin, R.; Craig, A.M.; Wendy Lou, W.Y.; Schwartz, B.; Rea, E. Temporal and spatial variation of heat-related illness using 911 medical dispatch data. Environ. Res. 2009, 109, 600-606. [CrossRef]

11. Bell, M.L. Ozone and Short-term Mortality in 95 US Urban Communities, 1987-2000. J. Am. Med. Assoc. 2004, 292, 2372. [CrossRef] [PubMed]

12. Hůnová, I.; Malý, M.; Řezáčová, J.; Braniš, M. Association between ambient ozone and health outcomes in Prague. Int. Arch. Occup. Environ. Health 2013, 86, 89-97. [CrossRef] [PubMed]

13. Li, J.; Woodward, A.; Hou, X.-Y.; Zhu, T.; Zhang, J.; Brown, H.; Yang, J.; Qin, R.; Gao, J.; Gu, S.; et al. Modification of the effects of air pollutants on mortality by temperature: A systematic review and meta-analysis. Sci. Total Environ. 2017, 575, 1556-1570. [CrossRef] [PubMed]

14. Ren, C.; Williams, G.M.; Mengersen, K.; Morawska, L.; Tong, S. Does temperature modify short-term effects of ozone on total mortality in 60 large eastern US communities?-An assessment using the NMMAPS data. Environ. Int. 2008, 34, 451-458. [CrossRef] [PubMed]

15. Jhun, I.; Fann, N.; Zanobetti, A.; Hubbell, B. Effect modification of ozone-related mortality risks by temperature in 97 US cities. Environ. Int. 2014, 73, 128-134. [CrossRef] [PubMed]

16. WHO. Review of Evidence on Health Aspects of Air Pollution—REVIHAAP Project; Technical Report; World Health Organization Regional Office for Europe: København, Denmark, 2013.

17. Burkart, K.; Canário, P.; Breitner, S.; Schneider, A.; Scherber, K.; Andrade, H.; Alcoforado, M.J.; Endlicher, W. Interactive short-term effects of equivalent temperature and air pollution on human mortality in Berlin and Lisbon. Environ. Pollut. 2013, 183, 54-63. [CrossRef] [PubMed]

18. Katsouyanni, K.; Analitis, A. Investigating the Synergistic Effects Between Meteorological Variables and Air Pollutants: Results from the European PHEWE, EUROHEAT and CIRCE Projects. Epidemiology 2009, 20, S264. [CrossRef]

19. Ren, C.; Williams, G.M.; Morawska, L.; Mengersen, K.; Tong, S. Ozone modifies associations between temperature and cardiovascular mortality: Analysis of the NMMAPS data. Occup. Environ. Med. 2008, 65, 255-260. [CrossRef]

20. Pascal, M.; Wagner, V.; Chatignoux, E.; Falq, G.; Corso, M.; Blanchard, M.; Host, S.; Larrieu, S.; Pascal, L.; Declercq, C. Ozone and short-term mortality in nine French cities: Influence of temperature and season. Atmos. Environ. 2012, 62, 566-572. [CrossRef] 
21. Scortichini, M.; De Sario, M.; de'Donato, F.; Davoli, M.; Michelozzi, P.; Stafoggia, M. Short-Term Effects of Heat on Mortality and Effect Modification by Air Pollution in 25 Italian Cities. Int. J. Environ. Res. Public Health 2018, 15, 1771. [CrossRef]

22. Analitis, A.; de' Donato, F.; Scortichini, M.; Lanki, T.; Basagana, X.; Ballester, F.; Astrom, C.; Paldy, A.; Pascal, M.; Gasparrini, A.; et al. Synergistic Effects of Ambient Temperature and Air Pollution on Health in Europe: Results from the PHASE Project. Int. J. Environ. Res. Public Health 2018, 15, 1856. [CrossRef] [PubMed]

23. Filleul, L.; Cassadou, S.; Médina, S.; Fabres, P.; Lefranc, A.; Eilstein, D.; Le Tertre, A.; Pascal, L.; Chardon, B.; Blanchard, M.; et al. The Relation Between Temperature, Ozone, and Mortality in Nine French Cities During the Heat Wave of 2003. Environ. Health Perspect. 2006, 114, 1344-1347. [CrossRef] [PubMed]

24. Bremner, S.A.; Anderson, H.R.; Atkinson, R.W.; McMichael, A.J.; Strachan, D.P.; Bland, J.M.; Bower, J.S. Short term associations between outdoor air pollution and mortality in London 1992-4. Occup. Environ. Med. 1999, 56, 237-244. [CrossRef] [PubMed]

25. Cheng, Y.; Kan, H. Effect of the Interaction Between Outdoor Air Pollution and Extreme Temperature on Daily Mortality in Shanghai, China. J. Epidemiol. 2012, 22, 28-36. [CrossRef] [PubMed]

26. Jacob, D.J.; Winner, D.A. Effect of climate change on air quality. Atmos. Environ. 2009, 43, 51-63. [CrossRef]

27. Chaxel, E.; Chollet, J.-P. Ozone production from Grenoble city during the August 2003 heat wave. Atmos. Environ. 2009, 43, 4784-4792. [CrossRef]

28. Guenther, A.B.; Zimmerman, P.R.; Harley, P.C.; Monson, R.K.; Fall, R. Isoprene and monoterpene emission rate variability: Model evaluations and sensitivity analyses. J. Geophys. Res. 1993, 98, 12609. [CrossRef]

29. Souri, A.H.; Choi, Y.; Li, X.; Kotsakis, A.; Jiang, X. A 15-year climatology of wind pattern impacts on surface ozone in Houston, Texas. Atmos. Res. 2016, 174-175, 124-134. [CrossRef]

30. Otero, N.; Sillmann, J.; Schnell, J.L.; Rust, H.W.; Butler, T. Synoptic and meteorological drivers of extreme ozone concentrations over Europe. Environ. Res. Lett. 2016, 11, 024005. [CrossRef]

31. Flynn, J.; Lefer, B.; Rappenglück, B.; Leuchner, M.; Perna, R.; Dibb, J.; Ziemba, L.; Anderson, C.; Stutz, J.; Brune, W.; et al. Impact of clouds and aerosols on ozone production in Southeast Texas. Atmos. Environ. 2010, 44, 4126-4133. [CrossRef]

32. Sun, W.; Hess, P.; Liu, C. The impact of meteorological persistence on the distribution and extremes of ozone. Geophys. Res. Lett. 2017, 44, 1545-1553. [CrossRef]

33. Camalier, L.; Cox, W.; Dolwick, P. The effects of meteorology on ozone in urban areas and their use in assessing ozone trends. Atmos. Environ. 2007, 41,7127-7137. [CrossRef]

34. Kerr, G.H.; Waugh, D.W. Connections between summer air pollution and stagnation. Environ. Res. Lett. 2018, 13, 084001. [CrossRef]

35. Zhang, J.; Gao, Y.; Luo, K.; Leung, L.R.; Zhang, Y.; Wang, K.; Fan, J. Impacts of compound extreme weather events on ozone in the present and future. Atmos. Chem. Phys. 2018, 18, 9861-9877. [CrossRef]

36. Schnell, J.L.; Prather, M.J. Co-occurrence of extremes in surface ozone, particulate matter, and temperature over eastern North America. Proc. Natl. Acad. Sci. 2017, 114, 2854-2859. [CrossRef] [PubMed]

37. Phalitnonkiat, P.; Hess, P.G.M.; Grigoriu, M.D.; Samorodnitsky, G.; Sun, W.; Beaudry, E.; Tilmes, S.; Deushi, M.; Josse, B.; Plummer, D.; et al. Extremal dependence between temperature and ozone over the continental US. Atmos. Chem. Phys. 2018, 18, 11927-11948. [CrossRef]

38. Shen, L.; Mickley, L.J.; Gilleland, E. Impact of increasing heat waves on U.S. ozone episodes in the 2050s: Results from a multimodel analysis using extreme value theory. Geophys. Res. Lett. 2016, 43, 4017-4025. [CrossRef] [PubMed]

39. Meehl, G.A. More Intense, More Frequent, and Longer Lasting Heat Waves in the 21st Century. Science 2004, 305, 994-997. [CrossRef]

40. Russo, S.; Sillmann, J.; Fischer, E.M. Top ten European heatwaves since 1950 and their occurrence in the coming decades. Environ. Res. Lett.s 2015, 10, 124003. [CrossRef]

41. Horton, D.E.; Skinner, C.B.; Singh, D.; Diffenbaugh, N.S. Occurrence and persistence of future atmospheric stagnation events. Nat. Clim. Chang. 2014, 4, 698-703. [CrossRef]

42. Meleux, F.; Solmon, F.; Giorgi, F. Increase in summer European ozone amounts due to climate change. Atmos. Environ. 2007, 41, 7577-7587. [CrossRef] 
43. Fenner, D.; Holtmann, A.; Krug, A.; Scherer, D. Heat waves in Berlin and Potsdam, Germany-Long-term trends and comparison of heat wave definitions from 1893 to 2017. Int. J. Climatol. 2019, 39, 2422-2437. [CrossRef]

44. Tan, J.; Zheng, Y.; Tang, X.; Guo, C.; Li, L.; Song, G.; Zhen, X.; Yuan, D.; Kalkstein, A.J.; Li, F.; et al. The urban heat island and its impact on heat waves and human health in Shanghai. Int. J. Biometeorol. 2010, 54, 75-84. [CrossRef] [PubMed]

45. Scherber, K. Auswirkungen von Wärme- und Luftschadstoffbelastungen auf vollstationäre Patientenaufnahmen und Sterbefälle im Krankenhaus während Sommermonaten in Berlin und Brandenburg. Ph.D. Thesis, Humboldt-Universität zu Berlin, Berlin, Germany, 2014.

46. Scherer, D.; Fehrenbach, U.; Lakes, T.; Lauf, S.; Meier, F.; Schuster, C. Quantification of heat-Stress related mortality hazard, vulnerability and risk in Berlin, Germany. DIE ERDE 2013, 144, 238-259. [CrossRef]

47. DWD Climate Data Center (CDC). Historical Daily Station Observations (Temperature, Pressure, Precipitation, Sunshine Duration, etc.) for Germany. Available online: Ftp://ftp-cdc.dwd.de/pub/CDC/observations_ germany/climate/daily/kl/ (accessed on 11 September 2018).

48. Murage, P.; Hajat, S.; Kovats, R.S. Effect of night-time temperatures on cause and age-specific mortality in London. Environ. Epidemiol. 2017, 1. [CrossRef]

49. Hajat, S.; Armstrong, B.; Baccini, M.; Biggeri, A.; Bisanti, L.; Russo, A.; Paldy, A.; Menne, B.; Kosatsky, T. Impact of High Temperatures on Mortality. Epidemiology 2006, 17, 632-638. [CrossRef] [PubMed]

50. Barnett, A.G.; Tong, S.; Clements, A.C.A. What measure of temperature is the best predictor of mortality? Environ. Res. 2010, 110, 604-611. [CrossRef] [PubMed]

51. Vaneckova, P.; Neville, G.; Tippett, V.; Aitken, P.; FitzGerald, G.; Tong, S. Do Biometeorological Indices Improve Modeling Outcomes of Heat-Related Mortality? J. Appl. Meteorol. Climatol. 2011, 50, 1165-1176. [CrossRef]

52. SenUVK Air Pollution Network. Senate Department for the Environment, Transport and Climate Protection. Available online: https://luftdaten.berlin.de/ (accessed on 10 December 2018).

53. EC Directive 2008/50/EC of the European Parliament and of the Council of 21 May 2008 on Ambient Air Quality and Cleaner Air for Europe. Available online: http://eur-lex.europa.eu/LexUriServ/LexUriServ.do?uri=OJ:L: 2008:152:0001:0044:EN:PDF (accessed on 30 April 2019).

54. DESTATIS. Rückgerechnete und fortgeschriebene Bevölkerung auf Grundlage des Zensus 2011-1991 bis 2011. 2016. Available online: https://www.destatis.de/DE/Themen/Gesellschaft-Umwelt/Bevoelkerung/ Bevoelkerungsstand/Publikationen/Downloads-Bevoelkerungsstand/rueckgerechnete-bevoelkerung5124105119004.pdf?_blob=publicationFile\&v=3 (accessed on 30 April 2019).

55. IPCC. Managing the Risks of Extreme Events and Disasters to Advance Climate Change Adaptation; Field, C.B., Barros, V., Stocker, T.F., Dahe, Q., Eds.; Cambridge University Press: Cambridge, UK, 2012; ISBN 9781139177245.

56. Jänicke, B.; Holtmann, A.; Kim, K.R.; Kang, M.; Fehrenbach, U.; Scherer, D. Quantification and evaluation of intra-urban heat-stress variability in Seoul, Korea. Int. J. Biometeorol. 2018. [CrossRef]

57. Mann, H.B.; Whitney, D.R. On a Test of Whether one of Two Random Variables is Stochastically Larger Than the Other. Ann. Math. Stat. 1947, 18, 50-60. [CrossRef]

58. Pattenden, S.; Armstrong, B.; Milojevic, A.; Heal, M.R.; Chalabi, Z.; Doherty, R.; Barratt, B.; Kovats, R.S.; Wilkinson, P. Ozone, heat and mortality: Acute effects in 15 British conurbations. Occup. Environ. Med. 2010, 67, 699-707. [CrossRef] [PubMed]

59. Sartor, F.; Snacken, R.; Demuth, C.; Walckiers, D. Temperature, ambient ozone levels, and mortality during summer, 1994, in Belgium. Environ. Res. 1995, 70, 105-113. [CrossRef] [PubMed]

60. Díaz, J.; Ortiz, C.; Falcón, I.; Salvador, C.; Linares, C. Short-term effect of tropospheric ozone on daily mortality in Spain. Atmos. Environ. 2018, 187, 107-116. [CrossRef]

61. Bae, S.; Lim, Y.-H.; Kashima, S.; Yorifuji, T.; Honda, Y.; Kim, H.; Hong, Y.-C. Non-Linear Concentration-Response Relationships between Ambient Ozone and Daily Mortality. PLoS ONE 2015, 10, e0129423. [CrossRef] [PubMed]

62. Oke, T.R. The energetic basis of the urban heat island. Q. J. R. Meteorol. Soc. 1982, 108, 1-24. [CrossRef]

63. Sadighi, K.; Coffey, E.; Polidori, A.; Feenstra, B.; Lv, Q.; Henze, D.K.; Hannigan, M. Intra-urban spatial variability of surface ozone in Riverside, CA: Viability and validation of low-cost sensors. Atmos. Meas. Tech. 2018, 11, 1777-1792. [CrossRef] 
64. Mukherjee, A.; Agrawal, S.B.; Agrawal, M. Intra-urban variability of ozone in a tropical city—characterization of local and regional sources and major influencing factors. Air Qual. Atmos. Health 2018, 11, 965-977. [CrossRef]

65. Kosnik, M.; Armstrong, B.; Romieu, I.; Kovats, R.S.; Wilkinson, P.; Kingkeow, C.; Vajanapoom, N.; Pattenden, S.; Nikiforov, B.; McMichael, A.J.; et al. International study of temperature, heat and urban mortality: The 'ISOTHURM' project. Int. J. Epidemiol. 2008, 37. [CrossRef]

66. WHO. WHO Air Quality Guidelines for Particulate Matter, Ozone, Nitrogen Dioxide and Sulfur Dioxide-Global Update 2005. Available online: https://apps.who.int/iris/bitstream/handle/10665/69477/ WHO_SDE_PHE_OEH_06.02_eng.pdf;jsessionid=B119F6E38AC90286F8A76DA361BF8189? sequence=1 (accessed on 30 April 2019).

67. Utembe, S.; Rayner, P.; Silver, J.; Guérette, E.-A.; Fisher, J.; Emmerson, K.; Cope, M.; Paton-Walsh, C.; Griffiths, A.; Duc, H.; et al. Hot Summers: Effect of Extreme Temperatures on Ozone in Sydney, Australia. Atmosphere 2018, 9, 466. [CrossRef]

68. Lacour, S.A.; de Monte, M.; Diot, P.; Brocca, J.; Veron, N.; Colin, P.; Leblond, V. Relationship between ozone and temperature during the 2003 heat wave in France: Consequences for health data analysis. BMC Public Health 2006, 6, 261. [CrossRef]

69. Pascal, M.; Le Tertre, A.; Saoudi, A. Quantification of the heat wave effect on mortality in nine French cities during summer 2006. Public Libr. Sci. Curr. 2012, 4, RRN1307. [CrossRef] [PubMed]

70. Gordon, C.J. Role of environmental stress in the physiological response to chemical toxicants. Environ. Res. 2003, 92, 1-7. [CrossRef]

71. Kalisa, E.; Fadlallah, S.; Amani, M.; Nahayo, L.; Habiyaremye, G. Temperature and air pollution relationship during heatwaves in Birmingham, UK. Sustain. Cities Soc. 2018, 43, 111-120. [CrossRef]

72. Breitner, S.; Wolf, K.; Devlin, R.B.; Diaz-Sanchez, D.; Peters, A.; Schneider, A. Short-term effects of air temperature on mortality and effect modification by air pollution in three cities of Bavaria, Germany: A time-series analysis. Sci. Total Environ. 2014, 485-486, 49-61. [CrossRef] [PubMed]

73. Laschewski, G.; Jendritzky, G. Effects of the thermal environment on human health: An investigation of 30 years of daily mortality data from SW Germany. Clim. Res. 2002, 21, 91-103. [CrossRef]

74. Lerchl, A. Changes in the seasonality of mortality in Germany from 1946 to 1995: The role of temperature. Int. J. Biometeorol. 1998, 42, 84-88. [CrossRef] [PubMed]

75. Levy, J.I.; Chemerynski, S.M.; Sarnat, J.A. Ozone Exposure and Mortality. Epidemiology 2005, 16, 458-468. [CrossRef] [PubMed]

(C) 2019 by the authors. Licensee MDPI, Basel, Switzerland. This article is an open access article distributed under the terms and conditions of the Creative Commons Attribution (CC BY) license (http://creativecommons.org/licenses/by/4.0/). 